\title{
COURIER SERVICE QUALITY FROM THE CLIENTS' PERSPECTIVE
}

\author{
ALEKSANDRA GULC
}

\begin{abstract}
A B S T R ACT
The aim of the study is a critical analysis of literature concerning the evaluation of courier service quality and verification if client expectations towards courier service quality change in time considering the perspective of future 5-10 years. Research methods include the theoretical analysis of scientific literature, CAWI survey and statistical analysis of obtained data.

The literature overview has shown the lack of clearly defined evaluation constructs of courier service quality together with the criteria and weight, one universal commonly used measuring scale for evaluation of the service quality, diversification of methods and measurement tools for the various groups of stakeholders of courier service. Moreover, it can be concluded that the research concerning the courier service quality has not considered the problem of aging of quality indicators. Research results by the author have proved that the expectations of clients using courier service change in time, some of them are exposed to the aging process (price) while others become more important (for example tele-technologies, modern packaging, and technical facilities). Moreover, the survey results have shown that the customer opinions can be the source of interesting and innovative ideas for the development of courier service in future.

The analysis of domestic and foreign literature allowed presenting the academia with an output concerning the evaluation of quality in the field of courier service. As a result, the theoretical and methodological gaps were revealed to expose potential fields for further research. The research results concerning different methods of service quality evaluation can be useful mainly for managers in courier enterprises. Moreover, the knowledge about changing expectations of clients allows adjusting courier proposals to customer needs to gain a competitive advantage in the global market.
\end{abstract}

KEY WORDS

courier service quality, criteria, evaluation

DOI: 10.1515/emj-2017-0004
Corresponding author:

Aleksandra Gulc

Bialystok University of Technology, Faculty of Management, International Chinese and Central-Eastern European Institute of Logistics and Service Science, Poland

e-mail: a.gulc@pb.edu.pl

\section{INTRODUCTION}

Recently, the courier, express and parcel market (CEP) has developed dynamically worldwide. For example, in Poland, in the period 2000-2015, the number of registered courier operators increased by $1400 \%$, while the volume of deliveries and revenue grew at double-digit pace (Urząd Komunikacji Elektronicznej, 2016). In the next few years, the global
CEP market is expected to grow by $3.5 \%$ reaching the value of USD 385.09 billion by 2019 (Global Courier..., 2014). Although courier services stand at the juncture of logistics and postal services, they have characteristic features, which differentiate them, for example, the specified delivery time with an accuracy to an hour, money back guarantee, receipt of the shipment, delivery to the addressee in door-to-door sys- 
tem, the ability to track the shipment in the tracking-tracing system, the role of specific messenger - courier. This specificity of courier services has become very attractive not only for many trading, manufacturing enterprises but also for individual clients. Moreover, the global trends should be considered, such as the higher popularity of e-commerce, development of small and medium enterprises, higher activity of exporters provide for the further growth of CEP market, increasing competition among operators and higher demands of clients (Marczuk et al., 2015). To face these challenges and remain on the competitive market, courier enterprises must focus on the improvement of service as one of the key strategic aims. Therefore, the subject of measuring service quality in a courier branch is important and presents an issue both for practitioners and researchers. As far as scientific research is concerned, the current trend over the last years is the relatedness between quality management and services (Olszewska, 2016). Among many aspects of quality management, the authors have conducted research to find and develop models and methods for measuring quality in the field of service (Urban, 2013). Considering the quality measurement, an interesting problem that was outlined by Franceschini et al. but remains unsolved by researchers, is the aging of quality indicators caused among other things by changing demands of service customers (Franceschini et al., 2000).

The purpose of the paper is a critical analysis of literature concerning the evaluation of courier service quality and verification, provided criteria that determine the courier service quality change in time in the perspective of the next 5-10 years. The first section includes the overview of the research achievement concerning the issue of measuring courier service especially the measurement methods and criteria of courier quality assessment. The second one is dedicated to the description of author's own pilot research concerning the present and future expectations of clients using courier service. Finally, the conclusions of the examination and future research implications are presented.

\section{LITERATURE REVIEW}

This section presents the critical literature review indicating the academic achievements in the field of courier service quality especially measuring methods and criteria of courier quality assessment aiming to systematize the knowledge and indicate possible research gaps. Unlike the academic output concerning the measurement of logistics service quality, there are only a few articles concerning the measurement of courier service quality in the world-wide literature (Gulc, 2016). Zhang et al. deliberate the method of courier quality service improvement called a TwoStage Quality Functional Deployment (QFD). The method is based on Parasurman, Zeithaml, Berry's model (PZB model), QFD and the fuzzy set theory. The aim of the method is to transform express service demand into the express service resources. The authors outline that this method in not only available to analyse the whole express industry but also can be adopted by the whole service sector. Although, first and second stage of the QFD research can effectively reduce and even eliminate the negatively influencing factors in service of internal enterprise, namely the gap 1-4 in the PZB model, it does not verify the fifth gap measuring the difference between the perceived and experienced service quality (Zhang et al., 2012).

The study of Liu and Liu investigates the express logistics service quality in Changdao County in China by scales developed according to SERVQUAL method and LSQ theoretical models. The service quality scale was based on five dimensions, including reliability, protection, security (assurance), empathy, and perception (tangibles). The questionnaire containing 25 items was formed considering specific demands for the shipping express service in the island county. The research sample was 300 questionnaires, but only 199 were valid. The author does not specify if the respondents were only individual or also companies. The results of the empirical research show that the expected values of customers are significantly different from the perceived ones, showing that customers are not satisfied with the service quality of express logistics providers in Changdao. The results have shown that the dimension of security (assurance) achieved the highest rate while protection received the lowest. The authors recommend that the scale developed in this study may need further testing. Moreover, the sample in this study was drawn from Changdao County; thus, the conclusions inferred may not be generalized to other regions (Liu \& Liu, 2014).

The paper of Ho et al. presents the application of the Logistic Service Quality (LSQ) model to determine the most important dimensions of client satisfaction from courier service. The model included the following variables: timeliness, condition/accuracy of 
order, quality of information, and availability/quality of personnel. A multiple regression analysis indicated that not timeliness but condition/accuracy of order was the strongest factor influencing customer satisfaction with courier service. However, due to the increasing expectation from customers, timeliness was perceived as an entry-level requirement for every company in the logistic industry. The quality of information was also found to have a strong influence on customer satisfaction, while availability/quality of personnel was not a significant factor. The research based on snowball sample of 200 individual respondents mainly students limits the generalizability of this study. Sampling respondents from various groups including working adults and business organisations might provide a different scope of service quality expectations among logistic service providers (Ho et al., 2012).

In Polish literature, there are only a few papers concerning courier service quality. Dyczkowska’s paper presents two groups of customers - individual and institutional, who buy transport-forwardinglogistics service (TFL) including courier service. The paper presented conditions decided about the choice of logistics operator and how customers assessed courier service quality and their satisfaction. The most popular criteria of services selection in TFL sphere both by the individual and institutional customer were a time of delivery, service quality, and price. The paper considered the specificity of courier service, but it did not specify the part of the supply chain of TFL service that was the subject of research. Moreover, the research sample was limited only to 30 individual clients and 45 institutional ones without distinction of their size. The author did not explain how the service quality should be understood by respondents. The research results could be confusing because apart from the service quality there were other separate criteria being rather the features of service quality for example timeliness, completeness of delivery, a small number of compliments (Dyczkowska, 2011).

Ratajczak and Lorenc analysed the data concerning the time of delivery in one local courier company in Poland, $X$-press Couriers. The data showed that the level of timeliness was very differentiated. The authors also analysed the reasons for client complaints indicating the timeliness, breakage, and loss of delivery. The research has the fragmentary character; it concerns one single company and presents only one aspect of the service quality, i.e. timeliness (Ratajczak \& Lorenc, 2015).
The research of Frąś was based on the SERVQUAL method. It was conducted in 2009 and 2012, on a sample of 400 respondents who were clients of courier service, but only 225 surveys were completed. The research was conducted by examining the expectations concerning the quality of courier service, as well as assessment of already experienced courier service. The perceived service measured as the difference of experienced and expected quality was assessed on the account of five service criteria: reliability (the ability to perform the promised service dependably and accurately), assurance (the knowledge and courtesy of employees and their ability to convey trust and confidence), tangibility (the appearance of physical facilities, equipment, personnel and materials), empathy (caring, individualized attention to customers) and responsiveness (the willingness to help customers and to provide prompt service). The lowest rated criterion was the third one - responsiveness, and the highest rated one was the first criterion - tangibility. It should be noted that compared to the results of the survey in 2009, the service quality improved slightly in 2012. The author did not characterize the research sample or explain if the questions in the survey were adopted into the specificity of courier service (Frąś, 2014).

The paper by Rutkowski et al. is a complex study on the conditions of courier service development, the role of courier service in the Polish economy and future trends of this branch. The paper includes the results of the survey, which aimed to present the role of courier service in creating the competitiveness of Polish companies. 81 companies, which took part in the survey had to choose the factors that determine the choice of courier service. The results showed that $98 \%$ of small and medium enterprises and $94 \%$ of large companies admitted that next-day delivery is the most important factor in choosing the courier service as well as the same-day delivery and delivery tracking. $76 \%$ of small and medium enterprises and $55 \%$ of large companies said that without the access to courier service, their international activity would be very limited. Although the research results are interesting, it would be reasonable to verify them with an extended research sample (Rutkowski et al., 2011).

The paper by Dmowski et al. concerns the evaluation of service in two courier companies from the perspective of 60 customers, mainly small companies. The research focused on a few operation areas of chosen courier enterprises, which are essential from the point of view of contractor needs. These were: 
Tab. 1. Overview of criteria for measuring courier service quality

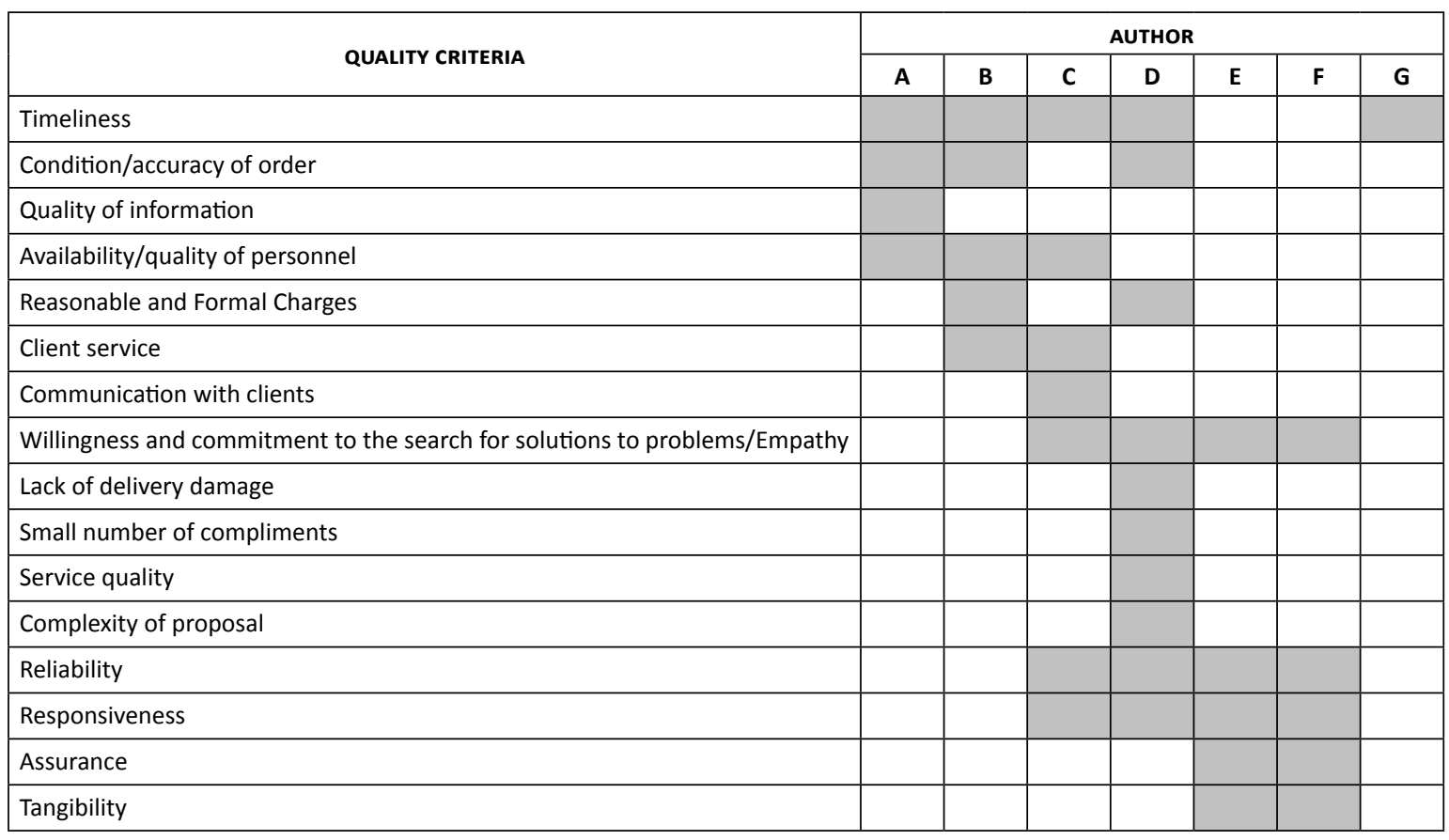

Source: author's elaboration on the basis of (A - Ho et al., 2012; B - Zhang et al. 2012; C - Dmowski et al., 2013; D - Frąś, 2014; F - Liu \& Liu, 2014; G - Ratajczak \& Lorenc, 2015).

knowledge and competence of staff, customer service level, time of response and courier service, communication between courier companies and clients, the willingness and commitment to the search for solutions to problems. In every case, the client (company) made the assessment of the significance of the criterion on a scale of values from "very low", to "average" and "very high". The research results have shown that the high overall assessment of the quality of the service provided by one of the two courier companies was caused by the highly-rated level of knowledge and competence of employees, fast response time for complex orders, and commitment of the employees in solving current problems of customers. The information collected in the study clearly proved that cooperation with the client, which means a high level of customer service, is an essential criterion for choice and continuous cooperation with couriers, and, thus, an essential part of building a competitive advantage (Dmowski et al., 2013).

Summing up, although the express branch has developed rapidly and the courier service quality is one of the key goals for courier operators on the competitive market, the overview of literature has shown that only a few authors focus their research interests on this aspect both in Poland and worldwide. Moreover, researchers have not still deliberated one universal set of criteria to assess courier service quality and each author proposed a different point of view. As Table 1 shows, some of them used general criteria based on the SERVQUAL method (E-F) while others propose more detailed ones (A-D). All proposed criteria do not consider changing demands of clients and current facilities offered by courier operators. Moreover, some studies focus on one group of respondents for example institutional clients (Rutkowski et al., 2011; Dmowski et al., 2013) or individual ones (Ho et al., 2012), while others compare both individual and institutional client evaluation (Dyczkowska, 2005). Moreover, in some cases, the research sample is not specified, or authors do not pay attention to characterizing the research sample (Frąś, 2014; Zhang et al., 2012; Liu \& Liu, 2014). As far as assessment methods of service quality are concerned, some researchers use the full version of the SERVQUAL method assessing the perceived and expected quality (Frąś, 2014; Zhang et al., 2012) while others examine only expectations of clients or experienced service quality (Dyczkowska, 2005; Dmowski et al., 2013; Rutkowski et al., 2011; Ho et al., 2012; Ratajczak \& Lorenc, 2015).

Based on the literature overview, some research gaps can be mentioned: the lack of a clearly defined evaluation constructs of courier service quality 
together with the criteria for their evaluation and weight, the lack of a commonly used measuring scale for the evaluation of the service quality, the lack of diversification of methods and measurement tools for various groups of stakeholders (service provider, service recipient - an individual and an institution). Moreover, it can be concluded that the research concerning the courier service quality have not considered the problem of the aging of quality indicators, which was outlined by Franceschini (Franceschini et al., 2000).

\section{RESEARCH METHODS}

In response to the identified research gap concerning the problem of the aging of quality indicators, the aim of the pilot research was to verify if criteria that determine the courier service quality change in time. The research was based on the Internet surveying technique CAWI. The survey was addressed to clients of courier service, both individuals and enterprises located in Poland. The main question in the questionnaire was to rate the features of courier service that were essential in choosing the service today and ascertain their importance in the next 5-10 years. The respondents had to rate the courier service according to the seven-point Likert scale with anchors ranging from "the least essential" to "the most essential". The data was collected from 30 May 2016 to 7 August 2016. Based on the literature overview and web-sites of courier companies, thirteen criteria of service quality were elaborated:

- time of delivery (1);

- $\quad$ service price (2);

- service availability and information (the availability of information about the company and the proposal, fixed working hours, the location of the collection points, ease of contact, etc.) (3);

- flexibility to handle the delivery in terms of time and place (4);

- ability to take advantage of additional service (notification of receipt by text message or email, charges on delivery, written proof of delivery, etc.) (5);

- comprehensive service - the ability to use the accompanying services (receipt of the waste, packaging, package pick-up, full logistics service, etc.) (6);

- service individualization (proposal matching to the needs of a specific client or industry) (7);
- modern technology (individual PUDO - PickUp DropOff point near houses or apartments instead of boxes, drones or robots as couriers, etc.) (8);

- tele-technologies (ICT, mobile apps, the ability to manage shipment tracking, the ability to generate reports, constant contact with the client, etc.) (9); modern packaging solutions (the variety of packaging, packaging availability, possibility of packaging by courier, the aesthetics of packaging, packaging customization, etc.) (10);

- competence and qualifications of the service provider (professionalism and preparation of the service provider, the knowledge, skills, etc.) (11);

- $\quad$ staff politeness (12);

- trust (the credibility and reliability of the company, honesty, etc.) (13), (Kawa, 2014; Liu \& Liu 2014; Dyczkowska, 2005; Anioł, 2015; Biznes raport... 2015; Frąś, 2014).

The research sample consisted of 231 respondents; however three of them were not the customers of courier service, so finally, 228 questionnaires were completed. Respondents of this study were $60 \%$ females and $40 \%$ males. Considering the age of respondents, the most active group of courier service clients was the one of the age from 18 to 55 years old, the least (0\%) - below 18 years of age (Fig. 1).

As far as the level of education is concerned, the majority of clients using courier service were those with a Master degree (64\%) while the minority those with the primary level of education.

Over a half of all respondents use courier service often, i.e. once a month (31\%) and more than once a month (29\%), while the minority (a quarter) of customers use the service less than once per quarter (Fig. 3).

In this pilot research, most of the respondents were individuals (73\%); however, $28 \%$ were enterprises. Surprisingly, $12 \%$ of enterprises were large, hiring over 250 employees (Fig. 4).

\section{RESEARCH RESULTS AND DISCUSSION}

The respondents had to assess the significance of thirteen criteria, which determine the choice of courier service at present and in the future (in 5-10 years). The collected answers were analysed statistically. Firstly, the average assessment of each criterion of courier service was calculated considering the 


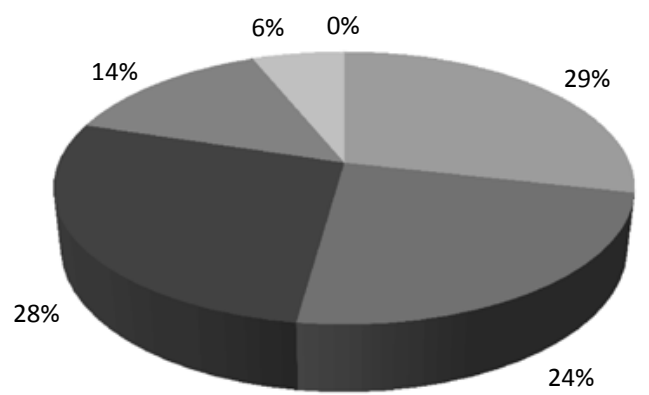

- below 18 years old

18-25 years old

-26-35 years old

—36-45 years old

46-55 years old

over 55 years old

Fig. 1. Age of respondents [\%]

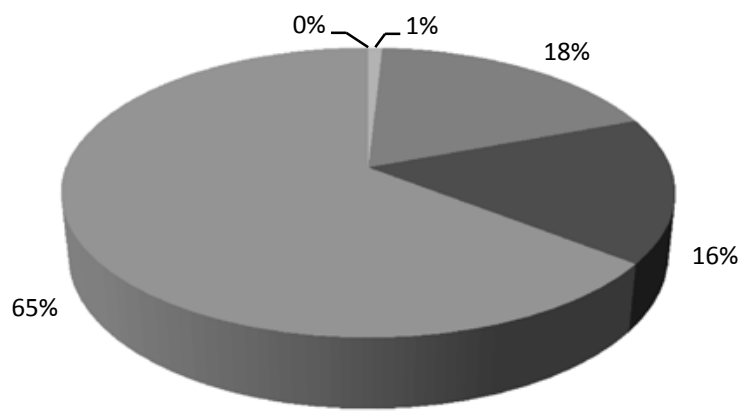

n Primary

national Vocational Qualification - Secondary

- Bachalor's degree

naster degree

Fig. 2. Education level of respondents [\%]

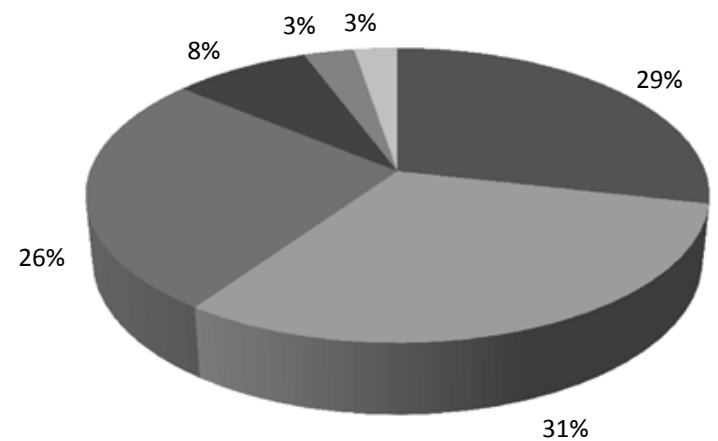

\author{
More often than once a month \\ Once a month \\ - Once a quarter \\ - Once a half year \\ - One a year \\ Rarly than once a year
}

Fig. 3. Frequency of courier service use [\%]

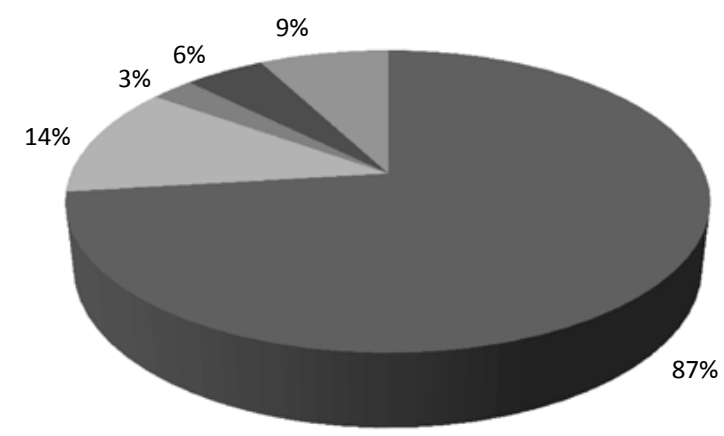

\title{
- Individuals
}

Enterprises below 10 employees

Enterprises with 10 to 25 employees

- Enterprises with 25 to 250 employees

Enterprises with over 250 employees

Fig. 4. Groups of respondents [\%] 


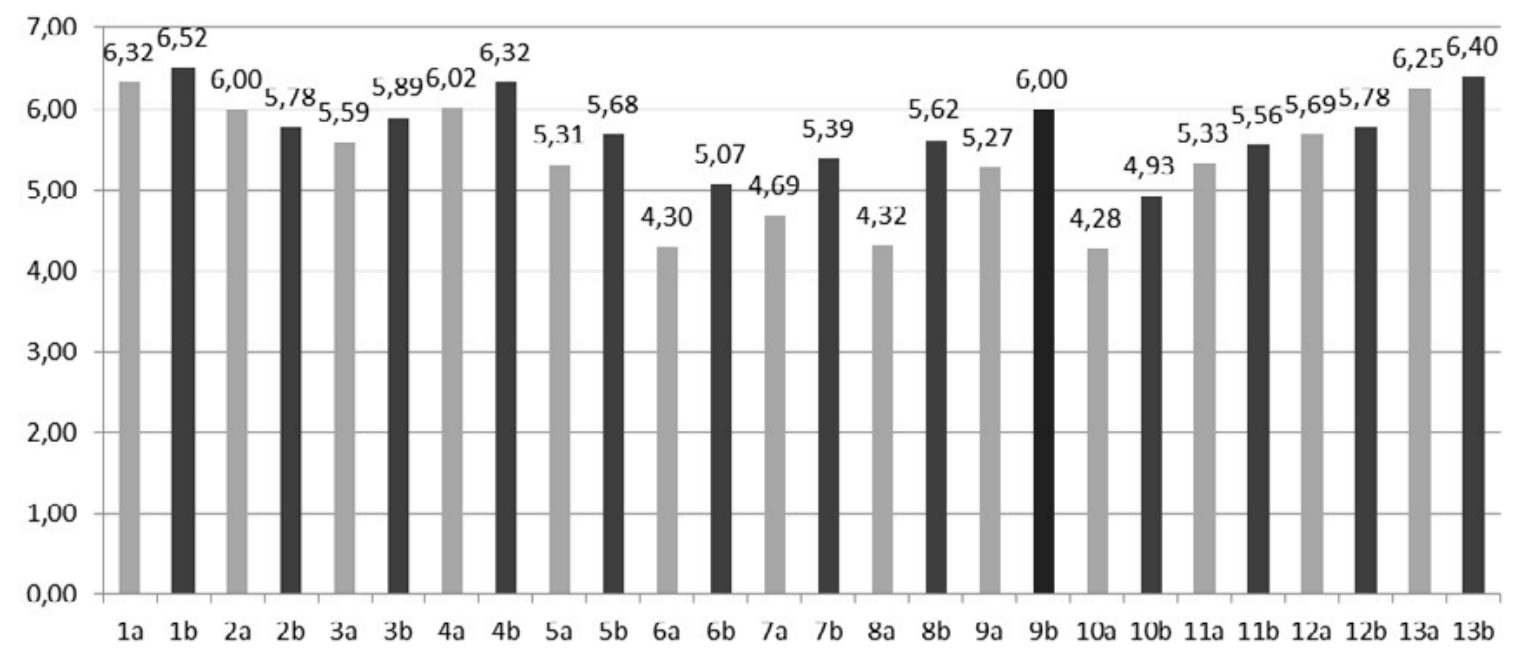

Fig. 5. Assessment of courier service quality at present (a) and in future (b)

present (a) and future assessment (b), (Fig. 5.). The obtained results were checked using the Wilcoxon signed-rank test - a non-parametric statistical hypothesis test used to compare two related samples. The differences between the two matched samples $(b-a)$ were statistically significant ( $\mathrm{p}<0.005$ in each case). Considering the assessment of the present service, the highly rated are a time of delivery (1a), trust (13a), flexibility (4a), and price (2a), while the least ones were comprehensive service (6a), modern technology (8a), and modern packaging solutions (10a). Similarly to other research, these results proved that one of the most important criteria for clients was a time of delivery and price but surprisingly also trust - reliability and honesty of courier enterprise as well as delivery flexibility, which is especially important for individual clients nowadays (Biznes raport..., 2015). As far as the future client demands are concerned, all of the criteria were assessed higher than at present, except for the price, the importance of which should decrease in future. In the perspective of 5-10 years, clients assessed that the most important criteria for them will be not a time of delivery ( $1 \mathrm{~b})$, trust (13b) and flexibility (4b) alone, as previous research showed, but also tele-technologies (9b).

Showing the difference between the significance of criteria in the future and nowadays (b-a), respondents think that the most rapid development would be seen in the importance of modern technologies, such as drones or individual pick-up \& delivery boxes, but also comprehensive service, service individualization, tele-technologies, and modern packaging solutions, which nowadays are not as important. In the case of time of delivery, staff politeness and trust, their increase in significance will be the lowest. The Fig. 6 also presents that the price will be a less important criterion for clients in the future than nowadays. Based on these results, it can be assumed that customers will not only pay attention to price or a time of delivery while choosing courier service but will also look for new technological solutions that will provide them comfort and individualised treatment.

The data presented in Table 2 indicates the percentage of respondent answers showing the difference between the future (b) and present expectations (a).

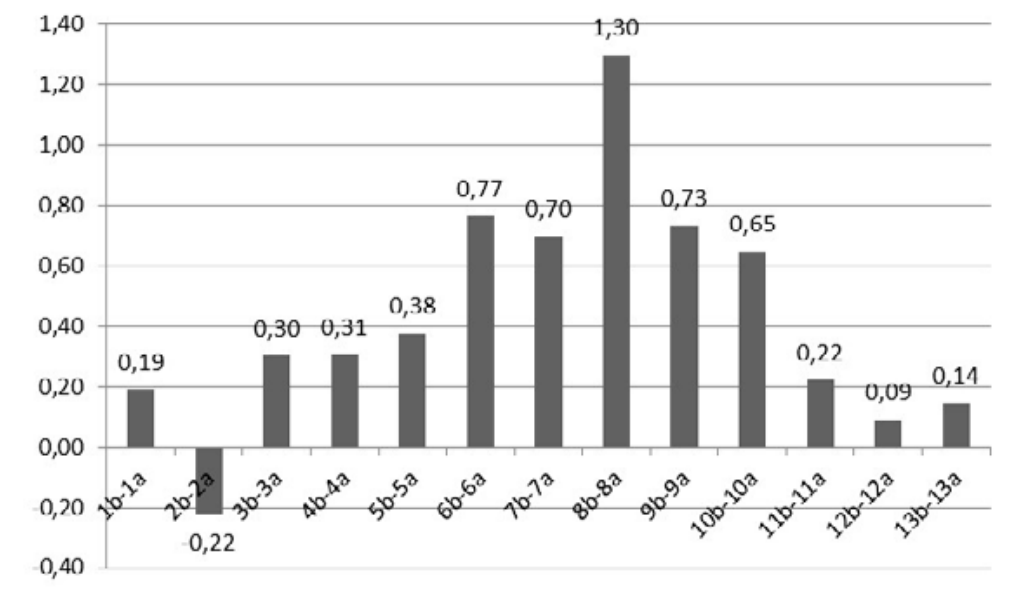

Fig. 6. Difference between the importance of criteria at present and in the future 
Tab. 2. Difference between significance of criteria today and in the future

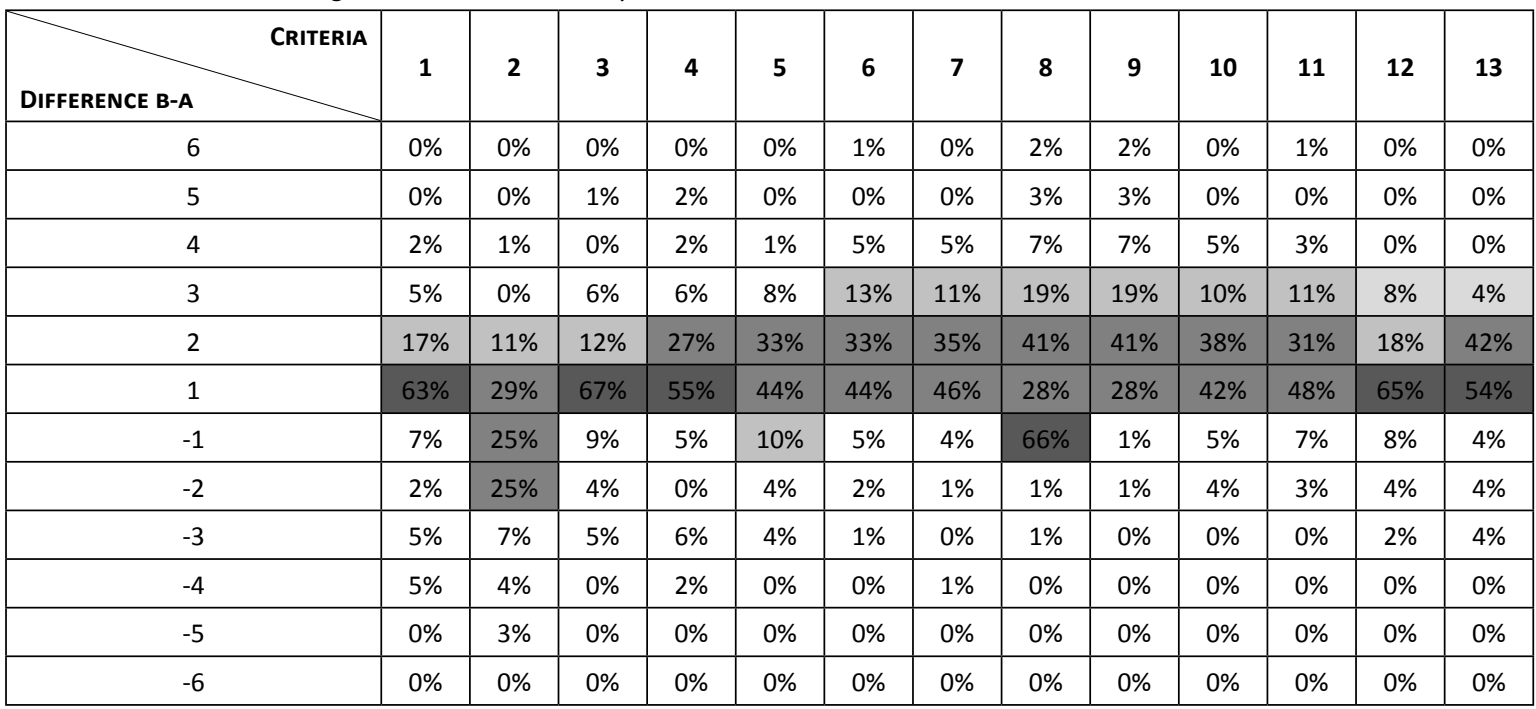

The difference between these two assessments $(b-a)$ is presented in the range $\langle-6 ; 6\rangle$. The greatest share of respondents pointed out the difference of importance at the level of 1 point: more than $50 \%$ of respondents chose this assessment for a time of delivery, service availability and information flexibility, staff politeness and trust (dark grey boxes). However, there were some deviations in responses at the level of 2 points and the greatest number of respondents was noted in the case of criteria 2 and 4-11 (grey boxes). Moreover, there were also the differences at the level of 3 points as the greatest number of respondents was observed in the case of criteria 6-11 (light grey boxes). The results proved that client expectations change in time, and in the case of some criteria, the difference between the present and future expectations is significant.

Moreover, the last question in the questionnaire was open and concerned other, unmentioned features of service that could be important for clients in the future. Apart from many similar criteria used in the prepared questionnaire, some respondents suggested interesting and new solutions in courier service for example:

- freely contacting the courier;

- cheap shipments from the place of client's residence;

- a greater flexibility of working hours of couriers;

- ability to redirect a shipment dynamically during the service from one option to another place, for example, change your delivery address to a different one or PUDO or another pick-up point;

- ability to return the ordered product directly to the courier;
- diversification of courier service, i.e. the development of forms food/laundry delivery as a form of click \& collect.

These propositions suggest that clients have constantly increasing expectations as well as they can be the source of inspiration and innovative ideas concerning courier service. Moreover, the knowledge about changing expectations of clients allow adjusting courier proposals to customer needs to gain a competitive advantage in the global market.

\section{CONCLUSIONS}

Considering current trends in the CEP market and the academic output concerning courier service, it can be concluded that the aspect of measuring the courier service quality is still a relevant part of management science and needs further research. The critical overview of literature has revealed that authors use different criteria and scales to measure the courier service quality. Moreover, the measuring criteria are not based on the current technical and technological achievements used by courier enterprises. The research is usually based on the same or slightly changed method despite the variety of measurement tools and methods available in service science. Moreover, it can be stated that the research in the courier service quality have not considered the problem of the aging of quality indicators. The results of author's pilot research have proved that client expectations change in time. Although the differences between the assessment of courier service quality 
at present and in the future are not very significant, the results show the future trends among courier service. Similarly to other research, the results have proved that nowadays one of the most important criteria for clients is a time of delivery and price, but surprisingly also trust and delivery flexibility (Biznes raport..., 2015). In the perspective of the next 5-10 years, the expectations of clients will increase in the case of all criteria, except for the price, the importance of which will decrease. In the future, clients believe that the most important criteria for them will be not a time of delivery, trust and flexibility alone as previous research suggested, but also tele-technologies. In the future, clients will choose a service that will be fast and comfortable. This is the reason to be interested in modern technical improvements, such as drones or individual pick-up \& delivery boxes, but also comprehensive service, service individualization, tele-technologies, and modern packaging solutions, which are not considered as important nowadays. The results of this research can be useful for courier enterprises to recognize future client expectations, but also to check if new solutions would be accepted by customers. Clients can also be the source of inspiration and innovative ideas concerning courier service. For further research, it is recommended to determine a universal set of criteria and measuring scale dedicated to courier service as well as conduct a broader research on future expectations of clients.

\section{ACKNOWLEDGEMENTS}

Studies have been carried out in the framework of the statutory work S/WZ/1/2014 and funded by the Ministry of Science and Higher Education.

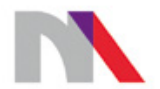

\section{Ministry of Science} and Higher Education

Republic of Poland

7th International Conference on Engineering, Project, and Production Management (EPPM2016) was financed in the framework of the contract no. 712/P-DUN/2016 by the Ministry of Science and Higher Education from the funds earmarked for the public understanding of science initiatives.

7th International Conference on Engineering, Project, and Production Management (EPPM2016) finansowana w ramach umowy 712/P-DUN/2016 ze środków Ministra Nauki i Szkolnictwa Wyższego przeznaczonych na działalność upowszechniającą naukę.

\section{LITERATURE}

Anioł, S. (2015, September 4-10). Kluczem do sukcesu jest oferta zintegrowana [The key to success is to offer integrated]. Gazeta Finansowa, 56.

Biznes raport: Koszty przesyłki przestały być najważniejsze, Rynek KEP w Polsce [Business report: shipping costs are no longer the most important thing, the KEP in Poland]. (2015, September 4-10). Gazeta Finansowa, 55.

Dmowski, P., Śmiechowska, M., \& Zelmańska, M. (2013). Jakość jako czynnik budujący przewage konkurencyjna na rynku ustug kurierskich [Quality as a factor in building a competitive advantage in the market for courier services]. Zeszyty Naukowe Uniwersytetu Szczecińskiego, 766, 167-179.

Dyczkowska, J. (2011). Klient na rynku usług TSL. Zeszyty Naukowe Wydziału Nauk Ekonomicznych Politechniki Koszalińskiej, 15, 119-134.

Frąś, J. (2014). Wybrane instrumenty pomiaru jakości usług logistycznych. Zeszyty Naukowe Uniwersytetu Szczecińskiego $n r$ 803. Finanse, Rynki Finansowe, Ubezpieczenia, 66, 297-317.

Gulc, A. (2016). Models and methods of measuring logistic service quality. 7-th EPPM Conference. Bialystok, 2016. Submitted to Procedia Engineering.

Ho, J. S. Y., Teik, D. O. L., Tiffany, F., Kok, L. F., \& The, T. L. (2012). Logistic Service Quality among Courier Services in Malaysia. 2012 International Conference on Economics, Business Innovation, 38, 113-117.

Kawa, A. (2014). Logistyka e-handlu w Polsce [Logistics of e-commerce in Poland]. Retrieved from http://www. google.pl/url? sa $=$ t\&rct $=j \& q=\& e s r c=s \&$ source $=w e b$ \&cd=1\&ved=0ahUKEwiF4aW8mYjQAhVMvxQK HZopDiYQFggcMAA\&url=http\%3A\%2F\%2Fme dia.pocztapolska.pl\%2Ffile\%2Fattachment\%2F6124 53\%2Fbb\%2Flogistyka-e-handlu-w-polsce.pdf\&usg $=\mathrm{AFQjCNFdsUVYpE2wgNtMX5HWX7pkhetw4w}$

Liu, L., \& Liu, Ch. (2014). Empirical Study of Express Logistics Service Quality -A Survey of Changdao County Express Sector. 2nd International Conference on Education Technology and Information System (ICETIS 2014), Atlantis Press, 542-546.

Marczuk, A., Caban, J., Porębska, E., Droździel, P., Duda, K. \& Mikulski M. (2015). Rynek i logistyka usług kurierskich $\mathrm{w}$ Polsce [The market and logistics courier services in Poland]. Logistyka, 3(CD 1), 3075-3084.

Olszewska, A. M. (2016). Research issues undertaken within quality management - overview of selected literature and a knowledge map. 7-th EPPM Conference. Bialystok, 2016. Submitted to Procedia Engineering.

Ratajczak, J., \& Lorenc, A. (2015). Ocena efektywności logistycznej obsługi klienta w branży KEP [Evaluating the effectiveness of the logistics customer service in the CEP branch]. Logistyka, 6, 1251-1261.

Rutkowski, K., Cichosz, M., Nowicka, K., \& Pluta-Zaremba, M. (2011). Branża przesyłek kurierskich, ekspresowych paczkowych. Wpływ na polska gospodarke [Courier, express and package branch. Impact on the Polish economy].Warszawa: Centrum Doradztwa i Ekspertyz Gospodarczych sp. z o.o. 
TechNavio. (2014). Global Courier, Express, and Parcel (CEP). Market 2015-2019.

Urban, W. (2013). Jakość usług w perspektywie klientów $i$ organizacji [Quality of service in term of clients and the organization]. Białystok: Oficyna Wydwnicza Politechniki Białostockiej.

Urząd Komunikacji Elektronicznej (2016). Raport o stanie rynku pocztowego za rok 2015 [Raport o stanie rynku pocztowego za rok 2015], Warszawa.

Zhang, Z., Baoqin, Y., Zhang, Sh., Wu, Sh., \& Xie, J. (2012). A Study of Courier Service Quality Improvement Based on a Two-Stage QFD. LISS 2012: Proceedings of 2nd International Conference on Logistics, Informatics and Service Science. Berlin Heidelberg: SpringerVerlag, 885-889. doi: 10.1007/978-3-642-32054-5_ 123. 